\title{
Mineralogical Reasons of Au Recovery Variability from North-Western Pit of Varvara Au-Cu Mine (Kazakhstan) and Criteria for Geometallurgical Mapping
}

\author{
I. Anisimov ${ }^{(\bowtie)}$, A. Dolotova, A. Sagitova, M. Kharitonova, \\ and I. Agapov \\ Polymetal Engineering JSC, Saint-Petersburg, Russia \\ anisimovis@polymetal.ru
}

\begin{abstract}
Varvara Au-Cu mine deposit is located in Northern Kazakhstan. Mineralization is hosted in volcano-sedimentary, sedimentary rocks, metamorphosed and altered ultramafic and felsic rocks. Variability study was done on 58 composite samples represented five mineral ore types: serpentine-chlorite-talc; carbonate-chlorite-talc; quartz-sulfide; pyroxene-chlorite-prehnite \pm garnet; quartz-feldspar \pm pyroxene \pm amphibole. Five processing ore types were defined: $\mathrm{Au}, \mathrm{Ni}-\mathrm{As}$, pyrite, $\mathrm{Cu}$ and mixed. Mineralogy and geochemical studies revealed separate mineral associations carrying $\mathrm{Cu}, \mathrm{Ni}-\mathrm{As}$ and $\mathrm{Au}$ mineralization. Flotation and cyanidation tests were performed for each sample. Au losses with cyanidation cake occurred due to locking in sulfides. Floatation concentrate contamination with $\mathrm{Mg}$-silicates (talc, serpentine) was connected to Au losses. Quartz-sulfide ore demonstrated better recovery by flotation. Cyanidation were most effective for pyroxene-chlorite-prehnite \pm garnet and quartz-feldspar \pm pyroxene ore compositions. Carbonate presence in the serpentine-chlorite-talc ore followed decrease in recovery by both extraction methods. Optimal viable ore treatment method can be chosen based on regression equations using ore chemical composition and color.
\end{abstract}

Keywords: Typification - Cyanidation - Flotation - Recovery estimation · Geometallurgy

\section{Introduction}

Varvarinskoe Au-Cu deposit is located in Kostanay region in Northern Kazakhstan and operated by several open pits. It is localized in volcanogenic, terrigenic, carbonate rocks $\left(\mathrm{D}_{2}-\mathrm{C}_{1}\right)$ with ultrabasic and granodiorite intrusions $\left(\mathrm{C}_{2}-\mathrm{C}_{3}\right)$. Silicification, argillic alteration, scarn processes were wide spread. Retrograde metamorphic changes were typical for ultramafic rocks.

This work was aimed at determining compositional differences in ore types and ore characteristics effected gold recovery by cyanidation and flotation. 


\section{Methods and Approaches}

58 small composite geometallurgical samples from Northwestern open pit were studied for bulk chemical and mineral composition, sample color with RGB-parameters. Cyanidation and sulfide flotation tests were done on the head samples.

$\mathrm{Au}$ was assayed with fire assay with atomic absorption finish, multi-element ICPAES assays after four acid digestion of samples and XRF-analysis, sulfide and total S, total C estimated by LECO AES analysis.

Mineral phase identification and their quantification was done using Eva software and COD database. Quantitative X-ray powder diffraction with Rietveld refinement was done using Topas software at Polymetal Engineering.

Multivariate statistical analysis was performed on filtered data with Aitchison transformation using Pearson correlations with Cytoscape software, PCA and regression analyses. Regression analysis was carried out to predict gold extraction.

\section{Results and Discussion}

Mineral composition of the samples varied between serpentine-talc-chlorite \pm carbonate, quartz-feldspatic and quartz-sulphide associations. Five main mineral ore types were distinguished based on bulk mineral composition: 1 - serpentine-chloritetalc, 2 - carbonate-chlorite-talc, 3 - quartz-sulfide, 4 - pyroxene-chlorite-prehnitegarnet, 5 - quartz-feldspar-pyroxene-amphibole.

Flotation and leaching tests revealed five processing ore types: a - gold, b - copper, c - Ni-As, d - pyrite and e - mixed.

Multivariate statistics analyses were performed on all available samples parameters including mineral and chemical composition; color (RGB, brightness - 1BRT and darkness - dBRT); material fineness $(-71 \mu \mathrm{A})$; $\mathrm{Au}, \mathrm{Cu}, \mathrm{As}, \mathrm{Ni}$, sulfidic $\mathrm{S}$, total $\mathrm{S}$ recovery to concentrate and losses to flotation tails (XF) ( $\mathrm{AuKF}, \varepsilon \mathrm{CuKF}, \varepsilon A s K F$, $\varepsilon N i K F, \varepsilon S s K F, \varepsilon S K F ; \varepsilon A u X F, \varepsilon C u X F, \varepsilon A s X F, \varepsilon N i X F, \varepsilon S s X F, \varepsilon S X F)$ and cyanidation $(\varepsilon A u C N, \varepsilon \mathrm{CuCN},-\varepsilon A u C N,-\varepsilon \mathrm{CuCN})$, parameters of cyanidation conditions (reagents uptake - $\mathrm{NaCNi}, \mathrm{CaCNi}$ ), cyano-soluble copper $-\alpha \mathrm{CuCNr}$, Au content in cake AuXvA, characteristics of gravity con (mass pull - $\gamma$ gk-t, pyrite, arsenopyrite, Crspinel, chalcopyrite, Ni-minerals contents in gravity con: PyMrcGK, ApyGK, ChrGK, CpyGK, NiMGK).

Pearson correlations revealed occurrence of 3 geochemical and mineral clusters following bulk sample mineralogy (Fig. 1): quartz-sulfide, diorite (feldspatic) and serpentinite. Au losses with cyanidation tails connected with Au locked in sulfides, which was proved with SEM study. S and $\mathrm{Cu}$ contents and $\mathrm{NaCN}$ consumption were included in the cluster with Au losses with cyanidation. This fact may point to consumption of free $\mathrm{CN}^{-}$by reaction with $\mathrm{S}^{0}$ and $\mathrm{Cu}$ dissolution, thus leading to deficit of free $\mathrm{CN}^{-}$. This reaction produced $\mathrm{CuCN}$ and rhodanates that could block surface gold particle impeding its dissolution. Concentrate contamination with self-floating $\mathrm{Mg}$ silicates (talc, serpentine) was connected to Au losses with flotation tails.

Principal component analysis exposed 7 principal components, which explained $72.1 \%$ of the total variance and described mineral composition, geochemical 


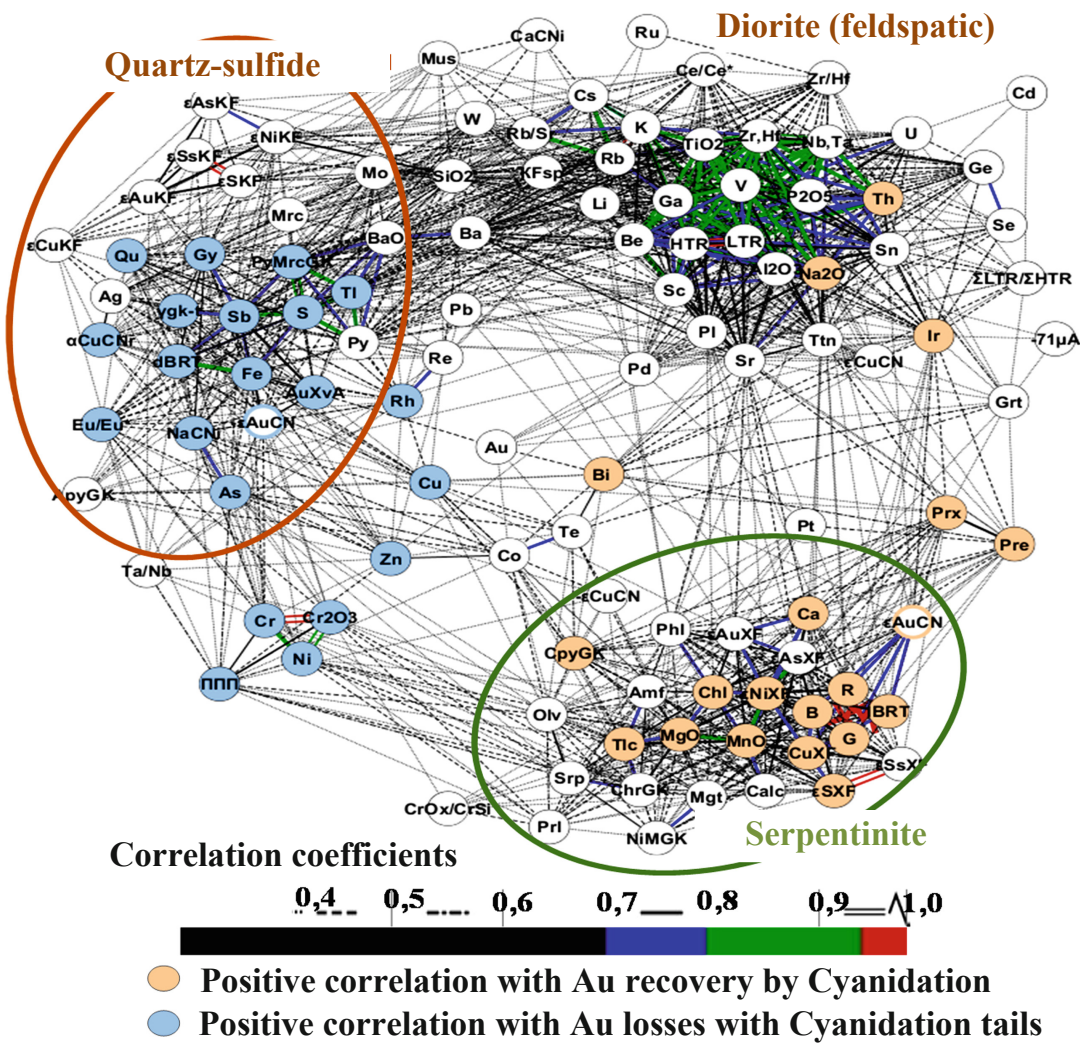

Fig. 1. Positive correlations between compositional and metallurgical parameters of samples from Varvara

associations, $\mathrm{Au}$ and $\mathrm{Cu}$ recovery by flotation and cyanidation (Fig. 2). 5 ore types were well separated in the coordinates of factors 2 and 3,2 and 4. Quartz-sulfide ore samples demonstrated better recovery by flotation, while cyanidation was more effective for samples with pyroxene-chlorite-prehnite-garnet and quartz-feldsparpyroxene-amphibole compositions. Carbonate occurrence in the serpentine-chloritetalc ore reduced recovery by both concentrating methods.

Regression equations for Au recovery by flotation $\left(\mathrm{R}^{2}=0.80\right)$ and by cyanidation $\left(\mathrm{R}^{2}=0.88\right)$ included color parameter (BRT) and elements contents (ppm or wt $\left.\%\right)$ :

$\boldsymbol{\varepsilon A u F l}=127.32+0.17 \mathrm{Co}-0.01 \mathrm{Cu}-4.78 \mathrm{Fe}(\%)+5.19 \mathrm{~K}(\%)+0.39 \mathrm{Mo}+0.39 \mathrm{Th}+0.01 \mathrm{Sb}-$ $0.63 \mathrm{BRT}+0.10 \mathrm{Zn}+0.43 \mathrm{Mg}(\%)+0.84 \mathrm{SiO} 2(\%)-0.81 \mathrm{Li}-0.40 \mathrm{Rb}-1.97 \mathrm{Te}+5.03 \mathrm{Cs}$

$\mathbf{E A u C N}=226.60-2.86 \mathrm{Ca}(\%)+0.30 \mathrm{Co}-7.00 \mathrm{Fe}(\%)-2.08 \mathrm{Sc}-0.16 \mathrm{Sr}+0.13 \mathrm{~V}$ $-0.24 \mathrm{MgO}(\%)-3.37 \mathrm{Al} 2 \mathrm{O} 3(\%)-0.55 \mathrm{SiO} 2(\%)+1.98 \mathrm{Ga}-0.42 \mathrm{BRT}+0.27 \mathrm{LOI}(\%)+$ $0.004 \mathrm{Cu}+0.02 \mathrm{Ni}-0.01 \mathrm{As}$ 


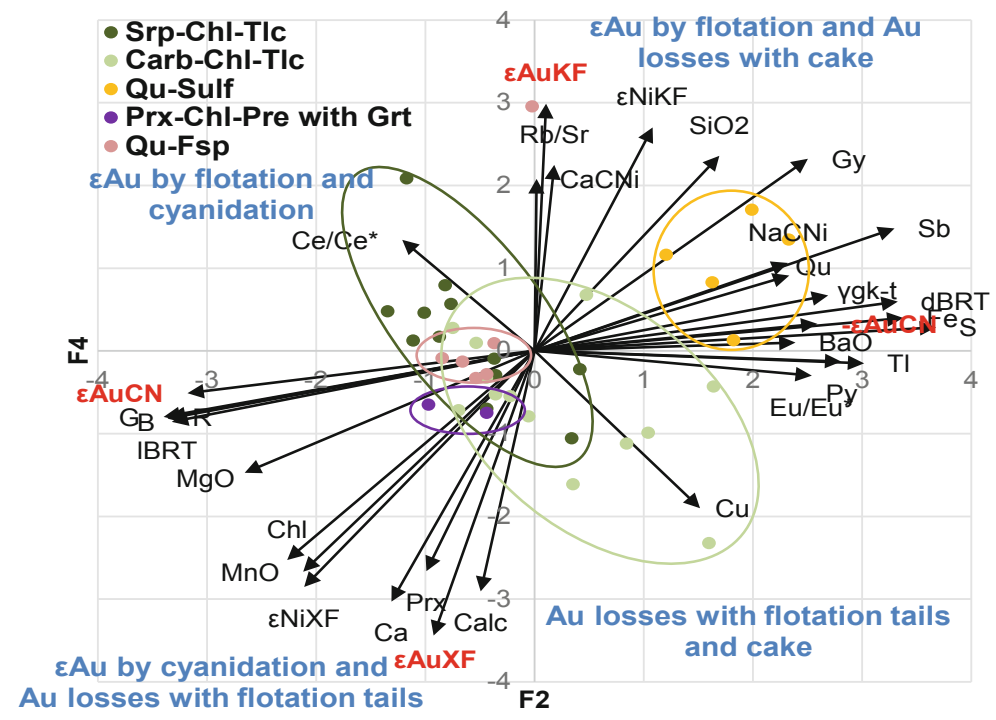

Fig. 2. Factor loadings and factor scores for factors 2 and 4 with interpretation

\section{Conclusions}

Mineral composition of the samples varied significantly from serpentine-talc-chlorite \pm carbonate to quartz-feldspar, skarn and quartz-sulfide associations. Au losses with cyanidation tails connected with Au locked in sulfides. Au losses with flotation tails connected to concentrate dilution with self-floating Mg-silicates (talc and serpentine). Ore sorting can be done based on regression equations of element composition and ore color to direct the ore to more economically viable process.

Acknowledgements. The authors are grateful to Nicolay Rylov for scientific advices, Lims-lab and Nati-R for collaboration.

Open Access This chapter is licensed under the terms of the Creative Commons Attribution 4.0 International License (http://creativecommons.org/licenses/by/4.0/), which permits use, sharing, adaptation, distribution and reproduction in any medium or format, as long as you give appropriate credit to the original author(s) and the source, provide a link to the Creative Commons license and indicate if changes were made.

The images or other third party material in this chapter are included in the chapter's Creative Commons license, unless indicated otherwise in a credit line to the material. If material is not included in the chapter's Creative Commons license and your intended use is not permitted by statutory regulation or exceeds the permitted use, you will need to obtain permission directly from the copyright holder.

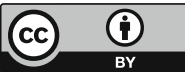

